\title{
MODELLING OF AN ACTUATOR IN THE VACUUM CONTROL SYSTEM OF AN AUTONOMOUS MILKING MACHINE
}

\author{
Stanisław Lis , Henryk Juszka, Mateusz Mendyk \\ Department of Power Engineering and Automation of Agricultural Processes, \\ University of Agriculture in Krakow \\ *Corresponding author: e-mail: stanislaw.lis@ur.krakow.pl
}

\begin{tabular}{l}
\hline ARTICLE INFO \\
\hline Article history: \\
Received: December 2015 \\
Received in the revised form: \\
February 2016 \\
Accepted: March 2016 \\
\hline Key words: \\
machine milking, \\
autonomous milking machine, \\
control, \\
simulation model \\
\hline
\end{tabular}

ABSTRACT
Design intents for an actuator of the suction pressure control system in
an autonomous milking machine were presented. For determination of
its dynamic properties step characteristic was taken. The considered
object was described with transmittance and thermodynamic models.
Models were identified and their parameters were adjusted. Computer
simulation was carried out in MATLAB ${ }^{\circledR}$-Simulink. Analysis of
research results proved that the thermodynamic model allows more
detailed reflection of dynamic characteristic of the real object. Its
degree of imperfections is $0.99 \%$. For the transmittance model
a degree of imperfection with the value of $2.02 \%$ was obtained.

\section{Introduction}

A growing milk efficiency of cows resulting in the extension of milking time and increase of physical loading of teats and udders may lead to udder conditions, inter alia, mastitis (Ipema and Benders, 1992; Neijenhuis et al., 2004). Another reason of diseases may be failure to consider individual properties with regard to milk-out. According to Ipem and Hogewerf (2008) who investigated individual properties of cows on account of milk volume and rate of milk - out there are significant statistical differences between particular quarters of cow's udder. Thus, it is necessary to undertake research works on development of new structures of milking machines and improved algorithms of automatic control of milking process.

Structure of a milking machine which includes individual properties of cows with regard to milk-out would result in improvement of health of dairy cows' udders (Naumann et al., 1998; Rasmussen et al., 1994).

It is believed that automatic control of vacuum as a function of milk flow-out, measured independently for each quarter of cow's udder would be an optimal solution (Davies et al., 2000). The structure of an autonomous milking machine (AAU) for operation in a milking robot corresponds to such requirements (Juszka et al., 2011; Tomasik et al., 2014). 


\section{Objective and scope of the study}

The objective of the paper was to develop simulation models of an actuator in the system of suction pressure control in an autonomous milking machine (AAU).

The objective of the paper included:

- presentation of design assumptions for the system of control of suction vacuum in AAU,

- experimental determination of dynamic properties of an actuator of vacuum control system AAU,

- development of a transmittance simulation model of an actuator,

- development of a thermodynamic simulation model of an actuator,

- identification of models by simulation in Matlab®-Simulink,

- graphic presentation of simulation results.

\section{Design intent for AAU}

A schematic representation which illustrates a structural intent for AAU and a general view of an actuator of the vacuum control system in AAU was presented in figure 1.

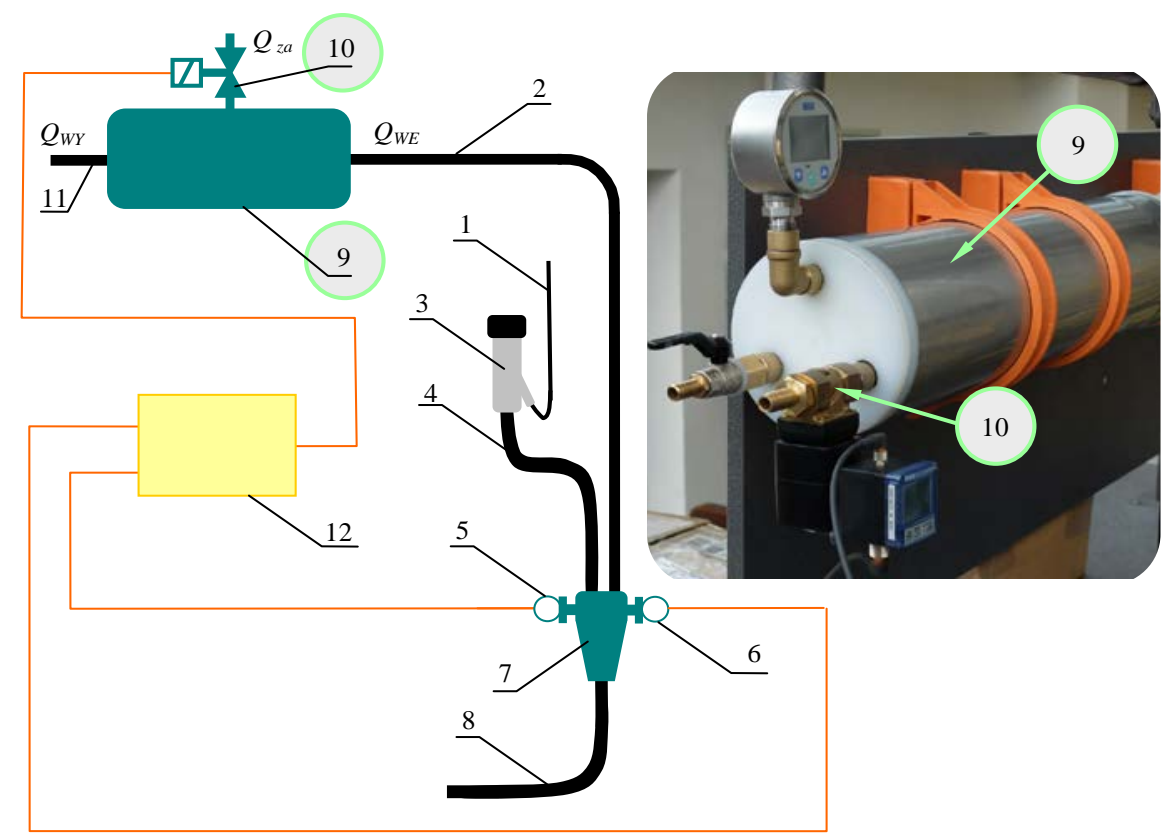

Figure 1. Schematic diagram of single columns of a milking machine with a general view of an actuator: 1 - pulsatory conduit, 2 - suction vacuum conduit, 3 - teat cup, 4- short milk tube, 5 - measure sensor of milk flow intensity , 6 - measure sensor of suction vacuum, 7 claw of autonomous milking machine, 8 - milk tube - transport vacuum, 9 - suction vacuum control container, 10 - electronic proportional valve, 11 - pressure installation conduit, 12 - controller 
Modelling of an actuator...

Suction vacuum is controlled by opening valve no. 10 and introduction of filtrated atmospheric air to container 9.

To this container through conduit 11 vacuum is supplied from vacuum installation.

The essence of the structure includes individual milking of each quarter of cow's udder including division of suction and transport vacuum.

The unit includes four identical independent two-chamber claws of special structure.

An actuator of the vacuum control system in the pneumatic installation is a container 9 with a valve 10 .

\section{Characteristics of the suction vacuum control system in the AAU column}

For control of the column of an autonomous milking machine a regulation system with a programming device which calculates the set value of vacuum based on the milk outflow from cow's udder was designed.

General assumptions for this control system were presented with a schematic diagram in figure 2.

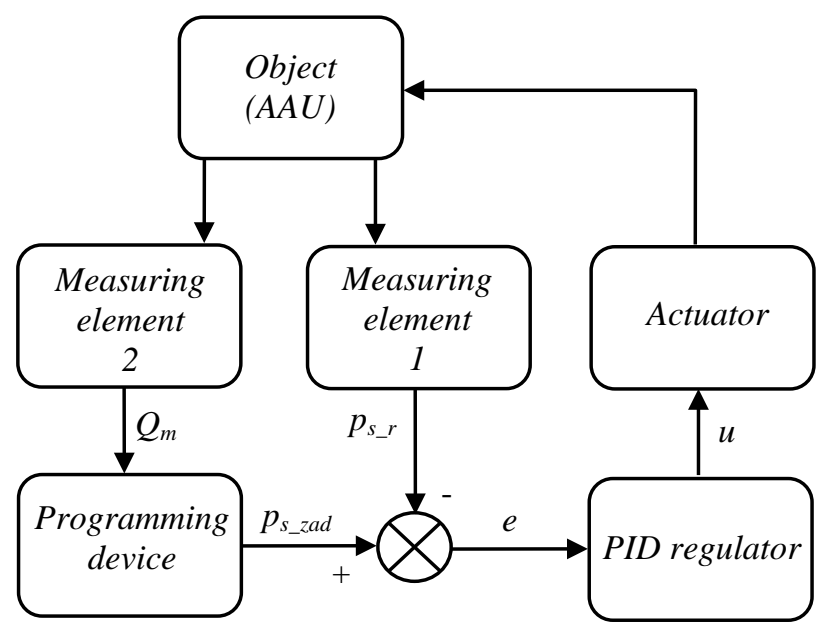

Figure 2. Flow chart of the closed suction vacuum control system

Tasks of functional blocks are as follows: measuring element 2 transfers a signal which includes information on the concentration of the stream of milk flowing out the cow's udder Qm. On this basis, a programming device calculates a set value of suction vacuum in an autonomous milking machine ps_zad. Signal of the set value meets then the summing knot input where it is compared to the signal which includes information from the measuring element 1 with the regulated value of suction vacuum in an autonomous milking machine ps_r. Difference calculated in the summing knot is a regulation error e.

A signal which represents it is introduced to the PID regulator input which calculates reverse impact on the regulation object $u$ carried out by an actuator unit - a container with an electronic proportional valve (fig. 1) (Juszka et al., 2015; Lis et al., 2007). 
Stanisław Lis, Henryk Juszka, Mateusz Mendyk

\section{Methodology}

The process of modelling of an actuator required identification of its dynamic properties.

Therefore, on the research stand a step characteristic was determined by means of an experiment. Then, the object was described with two simulation models - a transmittance and thermodynamic one (Tarnowski, 2008; Juszka et al., 2010). Models of an actuator were tuned and verified by comparison of their responses to simulated step function with a dynamic characteristic of a real object. The simulation result was presented graphically and discussed.

\section{Determination of dynamic properties of an actuator}

A flow chart and general view of the research stand for experimental identification of dynamic properties by determination of step characteristic for the process was presented in figure 3.
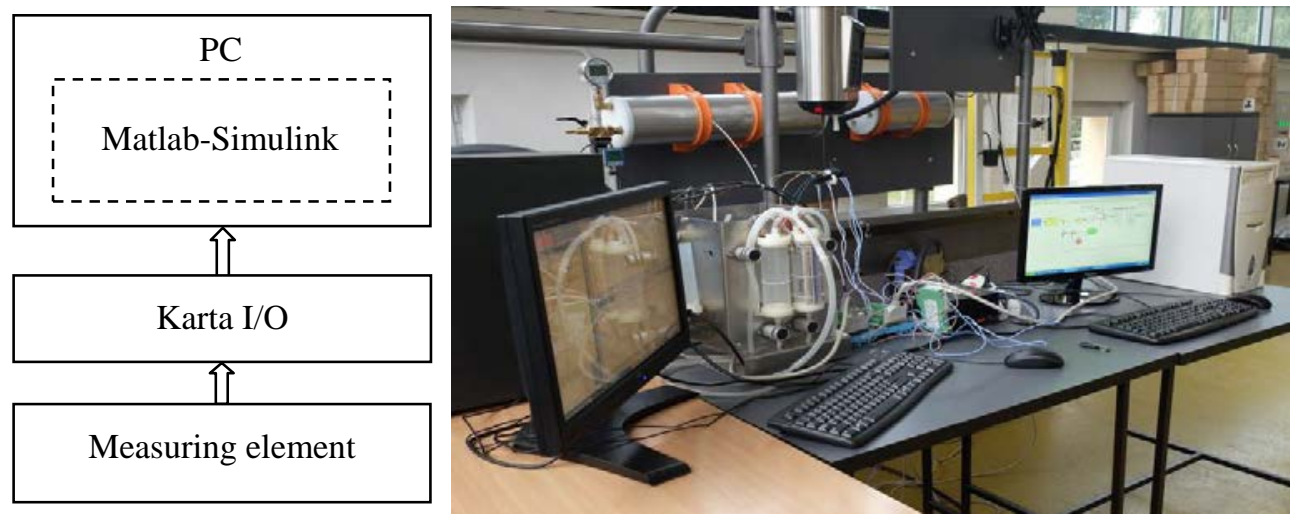

Figure 3. Measurement of step characteristic - flow chart with a general view of the research stand

The schematic diagram (on the left) presents a measurement system which uses MATLAB-Simulink environment with I/O card and a measuring element in the form of a pressure transducer. In order to experimentally determine a step characteristic of the analysed object a function was forced by a step increase of pressure in a container no. 9 .

It took place after valve no. 10 was opened. Thus, air from the surrounding was introduced to a container no. 9. Before enforcement was introduced, the object was in a determined state (fig. 1). After a step change of the input signal was obtained, the output signal (vacuum in the container) assumed a new value.

Its course which constitutes a step characteristic of the object was illustrated in figure 4. 


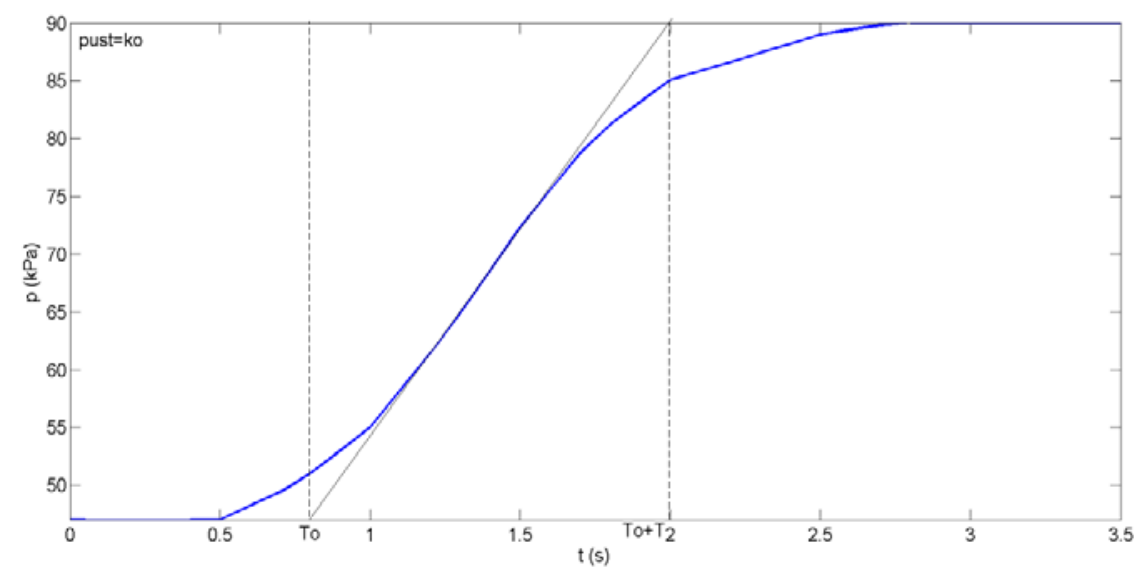

Figure 4. Step characteristic of the real object (absolute pressure)

\section{Simulation transmittance model of an actuator}

Based on the registered step characteristic an operator transmittance G(s) according to the relations was determined (Tarnowski, 2008):

$$
G(s)=\frac{\Delta y m(s)}{\Delta x(s)}=k_{o b} \frac{1}{T s+1} e^{-T o s}
$$

where:

$$
\begin{array}{ll}
\Delta x & \text { - change of the input signal, } \\
\Delta y m & \text { - change of the output signal, } \\
k_{o b} & \text { - coefficient of static strengthening of the object, } \\
T & \text { - time constant, } \\
T_{0} & \text { - transport delay. }
\end{array}
$$

This relation for the investigated object took the following form (2):

$$
G(s)=2,65 \frac{1}{0,7 s+1} e^{-0,29 s}
$$

\section{Simulation thermodynamic model of an actuator}

Based on the theoretical analysis of the nature of the phenomenon using thermodynamic relations an alternative model which describes an actuator was output.

The model, after Simulink's nomenclature, took the form of the functional blocks system illustrated with a schematic representation in figure 5 (Juszka et al., 2010; Kupczyk, 1988). 
Stanisław Lis, Henryk Juszka, Mateusz Mendyk

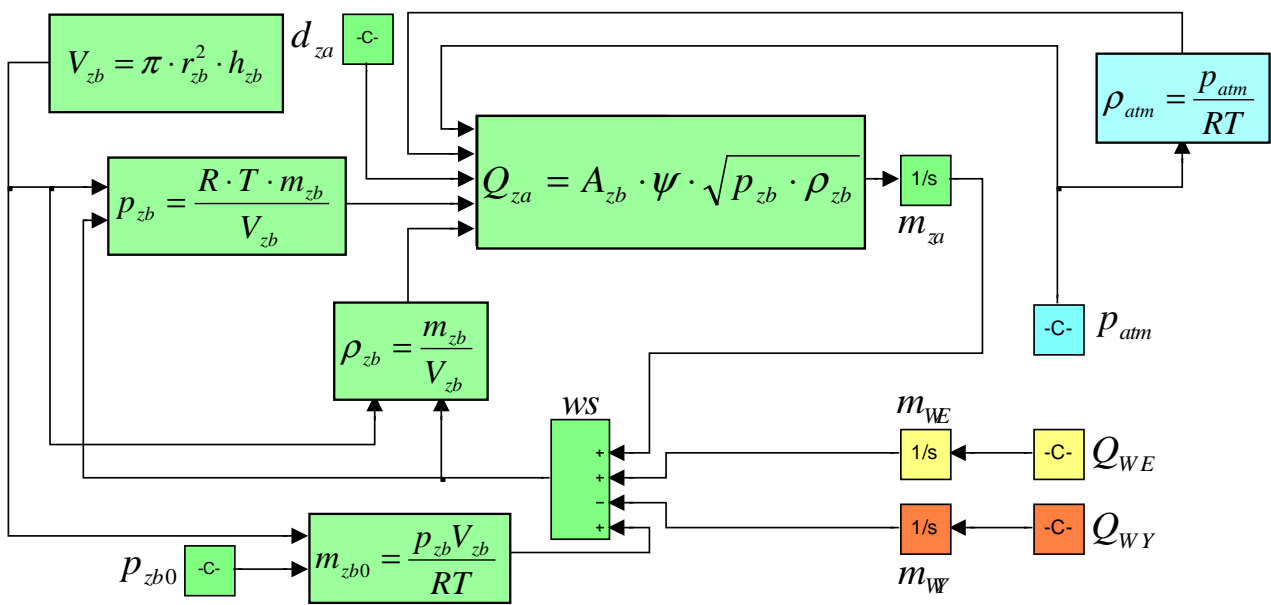

Figure 5. A thermodynamic model of an actuator

The following symbols are present in the schematic diagram: ws - a summing knot which calculates the mass of air flowing in and out of the container which controls suction vacuum; $V_{z b}$ - volume of a container $\left(\mathrm{m}^{3}\right) ; p_{z b}\left(p_{s \_r}\right)$ - air suction pressure (in a container) $(\mathrm{kPa}) ; Q_{z a}-$ mass stream of air flowing through a valve $\left(\mathrm{kg} \cdot \mathrm{s}^{-1}\right) ; Q_{W E}-$ mass stream of air flowing through the container input $\left(\mathrm{kg} \cdot \mathrm{s}^{-1}\right) ; Q_{W Y}$ - stream mass of air flowing through the container output $\left(\mathrm{kg} \cdot \mathrm{s}^{-1}\right) ; m_{z a}-$ mass of air flowing through a valve $(\mathrm{kg}) ; m_{W E}-$ mass of air flowing through the container input (kg); $m_{W Y}$ - mass of air flowing through the container output $(\mathrm{kg}) ; \rho_{z b}$ - air density in the container $\left(\mathrm{kg} \cdot \mathrm{m}^{-3}\right) ; m_{z b 0}$ - initial mass of air in the container $(\mathrm{kg}) ; p_{z b 0}$ - initial pressure in the container $(\mathrm{kPa}) ; p_{a t m}$ - atmospheric air pressure $(\mathrm{kPa}) ; p_{a t m}$ - atmospheric air density $\left(\mathrm{kg} \cdot \mathrm{m}^{-3}\right), d_{z a}$ - diameter representing degree of valve opening (m); $r_{z b}$ - radius of the container(m); $h_{z b}$ - length of the container (m); $A_{z a}-$ cross section area of the stream of air flowing through the valve (m2); $\psi$ - air flow coefficient; $m_{z b}$ - air mass in the container $(\mathrm{kg}) ; R$ - individual gas constant $\left(\mathrm{J} \cdot(\mathrm{kg} \cdot \mathrm{K})^{-1}\right) ; T$ - temperature $(\mathrm{K})$. The following assumptions were assumed for the purpose of this study: air is a perfect gas; impact of the surroundings on the controlled object does not change (constant temperature of $20^{\circ} \mathrm{C}$ and atmospheric pressure $-100 \mathrm{kPa}$. For calculation of the stream mass of air, the valve was replaced by an opening with convergent nozzles; absence of pressure fluctuations in the vacuum installation was assumed. Absolute value of air pressure was used in the calculations.

\section{Identification of models}

Identification of a model means determination of such values of its parameters, which ensure compatibility of model operation with known forms of activity of the analysed object. 
Modelling of an actuator...

Identification also understood as adjustment of a model serves for its adjustment to detailed needs of modelling of a specific technical system (Tadeusiewicz, 2014).

In the study for the suggested models, identification was carried out according to the schematic diagram presented in figure 6.

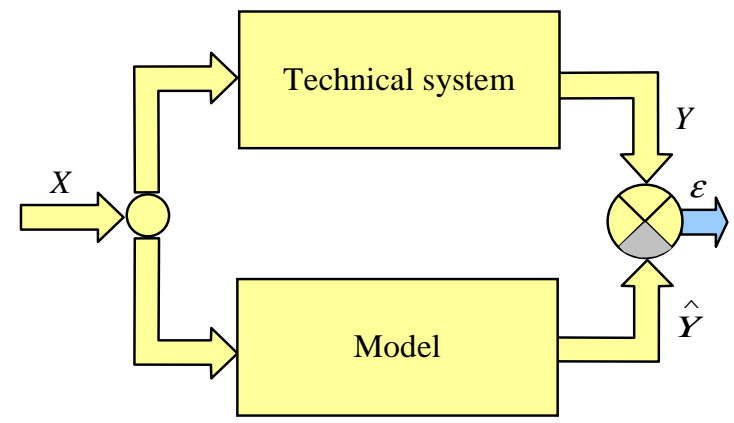

Figure 6. Schematic diagram of identification: $X$ - control signal (enforcement), $Y$-output signal of the system $\hat{Y}$ - output signal of the model, $\varepsilon$-degree of imperfections

During identification, models were adjusted and their degree of imperfection was determined.

Identification was carried out by simulation in Matlab-Simulink environment, which was initiated by introduction of step function on the input of the model.

Enforcement signal was simulated by the conditional instruction If. The condition of the model output as set with the course of dynamic characteristic of the real object read into the working space of Matlab. Figure 7 presents a schematic diagram of the simulation system which serves for identification of the transmittance model. For the thermodynamic model an analogous schematic diagram was presented (fig. 7).

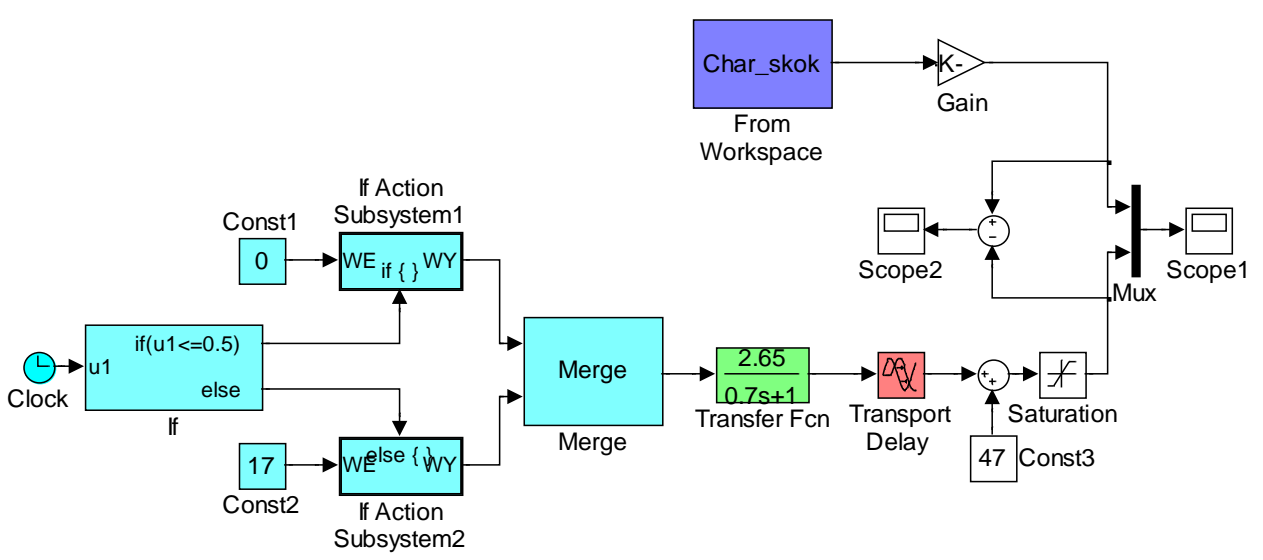

Figure 7. Flow chart of the model identification 
Figure 7 presents the following functional elements: blocks which constitute the conditional instruction If; blocks which represent a modelled object Transfer Fcn and Transport Delay; From Workspace block which serves for reading in to the working space of Matlab to Simulink, course of the step characteristic of a physical object taken out during and experiment; Mux block which enables presentation of two characteristics at the same time in the window of Scope block - thus, comparison of the real characteristic with the course calculated by the model will be possible.

Degree of imperfections calculated for models should be understood as a difference between the output signals of the real technical system and its model (Tadeusiewicz, 2014):

where:

$$
\varepsilon=Y-\hat{Y}
$$

$Y, \hat{Y}-$ analogically as in figure 6 .

In the study as a measure of degree of imperfections the following relation was used $\varepsilon_{i}$ :

$$
\varepsilon_{i}=\frac{1}{m} \sum_{t=1}^{m}\left|\frac{Y-\hat{Y}}{Y}\right|
$$

where:

$m \quad-\quad$ number of data, the remaining symbols as in figure 6 .

For the transmittance model value i was $2.01 \%$, and for the thermodynamic model it was $0.99 \%$.

Answers to the simulated step functions of adjusted models set with the course of the dynamic characteristic of the real object were presented in figure 8 .

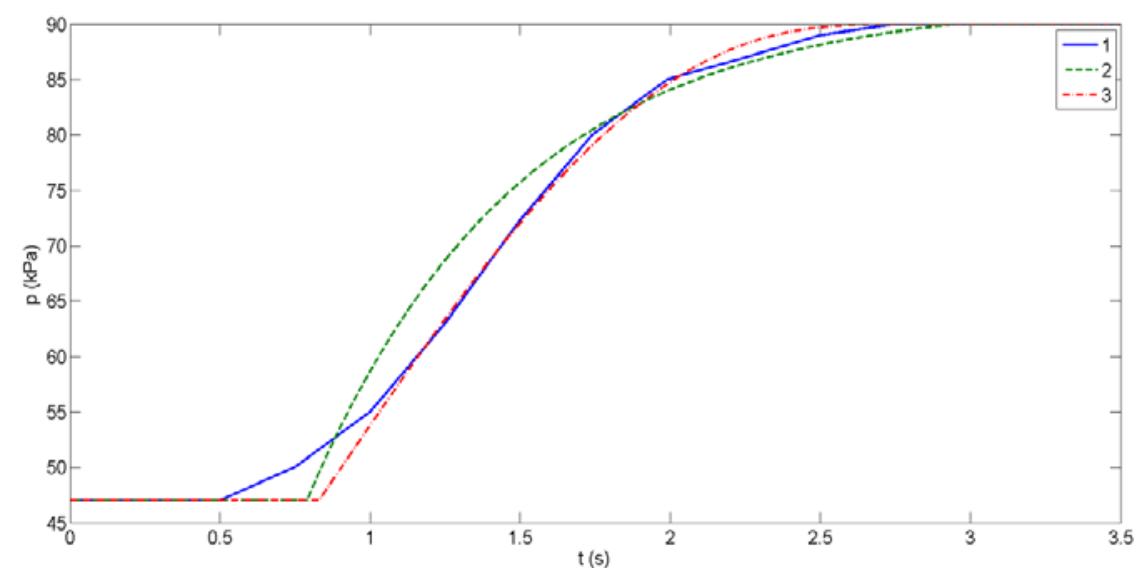

Figure 8. Dynamic characteristic (absolute pressure): 1 - real object, 2 - of the transmittance model, 3 - of the thermodynamic model 


\section{Discussion on results}

Analysis of the courses presented in figure 8 should lead to a conclusion that better adjustment was obtained in case of a thermodynamic model (line 3), whose input signal constitutes closer image of the real characteristics (line 1). The transmittance model ensured a less detailed result (line 2). Its course reflects real characteristic with more detail (line 1).

Based on the analysis of presented signals a justification can be made that the suggested models describe operation of an actuator in the system of suction vacuum control in AAU with sufficient detail. They constitute a basis for formulation of the vacuum control system model which will allow selection of settings for the milking process regulator.

These settings will be used for on-line simulation of equipment, which will provide a final confirmation of correctness of design intent. The research which was carried out constitutes a stage in improvement of the suction vacuum control system design in a milking machine.

\section{Conclusion}

1. Dynamic characteristics, registered for an actuator in the suction vacuum control system in an autonomous milking machine reflects an inertial proportional object.

2. Analysis of research results proved that a thermodynamic model allows more detailed reflection of dynamic characteristics of the real object.

3. Degree of imperfection $\varepsilon_{\mathrm{i}}$ of a model is $0.99 \%$.

4. For the transmittance model a degree of imperfection $\varepsilon_{\mathrm{i}}$ with the value of $2.01 \%$ was obtained.

5. Comparison of the dynamic characteristics with real characteristics of the object obtained due to suggested simulation models indicates that in the aspect of automation process the result of modelling provides information on the object operation with sufficient detail.

\section{References}

Davies, M.A.; Maltz, E.; Reinemann, D.J. (2000). Considerations of teat morphology and milking characteristics for robotic milking conditions. Proceedings of the International Symposium Robotic Milking. Lelystad, The Netherlands, 56-57.

Ipema, A.H.; Benders, E. (1992). Production, duration of machine-milking and teat quality of dairy cows milked 2, 3 or 4 times daily with variable intervals. Proceedings of the International Symposium on Prospects for Automatic Milking. Wageningen, Netherlands. EAAP Publication, Nr 65, 244-252.

Ipema, A.H.; Hogewerf, P., H. (2008). Quarter-controlled milking in dairy cows. Computers and electronics in agriculture, 62, 59-66.

Juszka, H.; Lis, S.; Tomasik, M. (2011). Koncepcja dwukomorowego kolektora autonomicznego aparatu udojowego. Inżynieria Rolnicza, 8(133), 161-165.

Juszka, H.; Lis, S.; Tomasik, M. (2015). Układ sterowania i stabilizacji podciśnienia ssacego w komorze podstrzykowej kubków udojowych dla krów. Uniwersytet Rolniczy w Krakowie. Kraków. Polska. Opis patentowy, A01J5/007, A01J5/04. WYN: P.403617.

Juszka, H.; Lis, S.; Tomasik, M. (2010). Modelowanie sterowania zbiornikiem akumulacyjnym w instalacji udojowej. Inżynieria Rolnicza, 1(119), 255-261. 
Kupczyk, A. (1988). Model dynamiki zmian podciśnienia w aparacie udojowym dojarki z rozdzielnym transportem mleka i powietrza. Cz. I. Model dynamiki zmian podciśnienia w kubku udojowym. Roczniki Nauk Rolniczych, T. 78-C-2, 173-181.

Lis, S.; Juszka, H.; Tomasik, M. (2007). Sterowanie podciśnieniem w autonomicznym aparacie udojowym. Inżynieria Rolnicza, 5(123), 129-135.

Naumann, I.; Fahr, R.D.; Lengerken, G. (1998). Zusammenhang zwischen dem Gehalt an somatischen Zellen in der Milch und ausgewählten Parametern der Milchflusskurve bei Kühen. Archiv für Tierzucht, 41(3), 237-250.

Neijenhuis, F.; Hillerton, J.E.; Paulrud, C.O.; Rasmussen, M.D.; Baines, J. (2004). Teat condition and mastitis. In: Proceedings of the Annual Meeting National Mastitis Council, vol. 43, 122-131.

Rasmussen, M.D.; Frimer, E.S.; Decker, E.L. (1994). Reverse pressure gradients across the teat canal related to machine milking. J. Dairy Sci. 77, 984-993.

Tadeusiewicz, R. (2014). Biocybernetyka. Wyd. Naukowe PWN, Warszawa, ISBN 978-83-01-17376-0.

Tarnowski, W. (2008). Projektowanie uktadów regulacji automatycznej ciaglych z liniowymi korektorami ze wspomaganiem za pomoca Matlab'a. Wyd. Uczelniane Politechniki Koszalińskiej, Koszalin, ISSN 0239-7129.

Tomasik, M.; Juszka, H.; Lis, S. (2014). Kolektor autonomicznego aparatu udojowego. Uniwersytet Rolniczy w Krakowie. Kraków. Polska. Opis patentowy. A01J5/04. WYN: P.399045.

\section{MODELOWANIE ZESPOLU WYKONAWCZEGO W UKLADZIE STEROWANIA PODCIŚNIENIEM AUTONOMICZNEGO APARATU UDOJOWEGO DLA KRÓW}

Streszczenie. Przedstawiono założenia projektowe dla zespołu wykonawczego układu sterowania podciśnieniem ssącym w autonomicznym aparacie udojowym. Dla określenia jego właściwości dynamicznych na stanowisku badawczym zdjęto charakterystykę skokową. Rozpatrywany obiekt opisano modelami: transmitancyjnym i termodynamicznym. Modele zidentyfikowano i dostrojono ich parametry. Przeprowadzono symulację komputerową w programie MATLAB ${ }^{\circledR}$-Simulink. Analiza wyników badań wskazała, iż model termodynamiczny pozwala na dokładniejsze odwzorowanie charakterystyki dynamicznej obiektu rzeczywistego. Jego stopień niedoskonałości $\varepsilon_{i}$ wynosi $0,99 \%$. Dla modelu transmitancyjnego otrzymano stopień niedoskonałości $\varepsilon_{i}$ o wartości $2,01 \%$.

Słowa kluczowe: dój maszynowy krów, autonomiczny aparat udojowy, sterowanie, model symulacyjny 